\title{
Hyperemesis Gravidarum and Cerebral Electrophysiology Determination of Cerebral Localization through Electroencephalography Signal Processing
}

\author{
Hiperemezis Gravidarum ve Serebral Elektrofizyoloji: Elektroensefalografi Sinyal İşleme
} Yöntemi ile Serebral Lokalizasyon Belirleme

Hakan Ahmet Ekmekçi1 ${ }^{1}$ Arzu Setenay Yılmaz², Muhammet Üsame Öziç33, Yüksel Özbay33, Özlem Seçil Kerimoğlu², Çetin Çelik ${ }^{2}$, Şerefnur Öztürk ${ }^{1}$

1Selçuk University Faculty of Medicine, Department of Neurology, Konya, Turkey 2Selçuk University Faculty of Medicine, Department of Obstetrics and Gynecology, Konya, Turkey ${ }^{3}$ Selçuk University Faculty of Engineering, Electrical and Electronics Engineering, Konya, Turkey

\section{Summary}

Objective: Hyperemesis gravidarum (HG) is a disease characterized by excessive vomiting and nausea during pregnancy. It differs from normal pregnancy where simple nausea and vomiting are seen frequently with unknown cause. The place and role of the brain in HG is unknown.

Materials and Methods: Thirty-three healthy pregnant women and 30 patients diagnosed with HG admitted to Selçuk University Faculty of Medicine, Obstetrics and Gynecology Department were included and electroencephalograph (EEG) signals of all patients obtained at Neurology Department were examined. These signals were evaluated with high math and examined with developed engineering methods. The sampling frequency of the EEG was $200 \mathrm{~Hz}$. Data were obtained in the frequency-power axis using $0.1 \mathrm{~Hz}$ frequency resolution, Hamming windowing, and 0.5 overlap ratio with signals on the time axis on all channels. All sub-bands have formed with unearthed power spectral density as delta, theta, alpha, and beta and after being created was calculated spectral densities.

Results: As a result, while showing significant changes as delta band for Fp1F3, theta band for C3P3, F3C3, Fp1F3, P3O1, T5O1, for other channels and subbands has not seen any significant changes with regard to average power spectral density.

Conclusion: HG and normal pregnancies, when examined in terms of power spectral density, abnormalities were observed in the EEG signals in the left hemisphere frontal area of the delta band, fronto-centro-parietal, and parietal-occipital areas of the theta band. In light of the literature, neither cerebral abnormalities in HG could be displayed nor the place of abnormality could be shown. However, this study is the first to clearly show abnormalities of theta-delta band activity and differences of locations in the left cerebral hemisphere.

Keywords: Hyperemesis gravidarum, pregnancy, electroencephalograph, spectral power density

Öz

Amaç: Hiperemezis gravidarum (HG) hamilelik sırasında aşırı kusma ve bulantının ortaya çıkardığı bir hastalıktır. Normal gebelikte sıklıkla görülen basit bulantı ve kusmadan farklı olarak sebebi tam olarak bilinmeyen bir durumdur. Beynin HG'deki yeri ve rolü tam bilinmemektedir.

Gereç ve Yöntem: Selçuk Üniversitesi Tıp Fakültesi, Kadın Doğum Polikliniği’ne başvuran HG tanısı alan takipli 30 hastanın ve 33 normal gebenin hamilelik dönemlerine göre Nöroloji Anabilim Dalı'nca elde edilen elektroensefalografi (EEG) sinyalleri incelenmiştir. Bu sinyaller, yüksek matematik ve gelişmiş mühendislik yazılımları ile irdelenmiştir. EEG örnekleme frekans $200 \mathrm{~Hz}$ 'dir. Tüm kanallarda bulunan zaman eksenindeki sinyaller Welch yöntemi ile 0,1 $\mathrm{Hz}$ frekans çözünürlüğü, Hamming pencereleme ve 0,5 örtüşme oranı kullanarak frekans-güç ekseninde veriler elde edilmiştir. Ortaya çıkarılan güç spektral

Address for Correspondence/Yazışma Adresi: Hakan Ahmet Ekmekçi MD, Selçuk University Faculty of Medicine, Department of Neurology, Konya, Turkey Phone: +905321551650 E-mail: hekmekci@yahoo.com

Received/Gelis Tarihi: 28.11 .2015 Accepted/Kabul Tarihi: 06.03 .2016

This study was presented as a poster in $51^{\text {th }}$ National Neurology Congress (27 November-3 December 2015, Antalya). 
yoğunluğu ile tüm alt bantlar delta, teta, alfa ve beta olmak üzere oluşturulmuş ardından güç spektral yoğunlukları hesaplanmıştır. Her bir frekans alt bantı güç yoğunluğu o kanaldaki 0,5-30 Hz arası toplam güç yoğunluğuna bölünerek ortalama değerler göreceli olarak elde edilmiştir.

Bulgular: Sonuç olarak ortalama güç yoğunluğu bakımından Fp1F3 için delta band1, C3P3, F3C3, Fp1F3, P3O1, T5O1 için teta bant1 anlamlı değişiklik gösterirken, diğer kanallar ve alt bantlarında anlamlı fark görülememiştir $(\mathrm{p}<0,05)$.

Sonuç: HG ve normal gebelerde EEG sinyalleri güç spektral yoğunluğu bakımından incelendiğinde sol hemisferin frontal alanında delta bandı, fronto sentroparietal, parieto-oksipital alanlarda teta bantı anormalliği gözlenmiştir. Literatür ışığında bakıldı ̆̆ında HG’nin serebral aktivite anormalliği net gösterilemediğgi gibi yeri de tam belirlenememiştir. Ancak bu çalışmamızda olasılıkla ilk kez sol serebral hemisferin teta-delta bant aktivite anormalliği ve lokalizasyon farklılıkları gösterilmiştir. Bu nedenle rutin EEG çekimlerine spektral güç analizi yapılarak HG olguların ayırıcı tanısında yardımcı olabilecek bir lokalizasyon tespit edilmiştir.

Anahtar Kelimeler: Hiperemezis gravidarum, gebelik, elektroensefalografi, spektral güç yoğunluğu

\section{Introduction}

Nausea-vomiting is a common problem of pregnancy, during which significant metabolic and physiologic changes occur. It has biologic, pharmacologic, psychologic, and behavioral aspects. Nausea-vomiting during pregnancy is considered as a routine part of pregnancy and generally people do not put an emphasis on it (1). The basic neural pathway of nausea-vomiting uses the autonomic nervous pathway. Nausea, vomiting, and gagging have different causes (2). Unlike a simple reflex activity, what causes vomiting, how and at which severity vomiting occurs, and the threshold value for vomiting are very complex and variable parameters (2). A modulation occurs that involves a brain-stem circuit composed of opioid receptors/cannabinoid system, which is partially suppressed with anti-emetic treatments (3). Another emphasized concept is 'the vomiting center'. Blockage of several types of vomiting by neurokinin 1 receptor antagonist drugs support the presence of such a pathway (4). The nucleus tractus solitarius (NTS) is located in lower brainstem and takes inputs from cerebral structures, vestibular system, area postrema, and intestinal structures, and forms the basis for vomiting $(1,5)$. The clinical picture observed during pregnancy is named nausea-vomiting of pregnancy (NVP). In some patients, this process can get out of control and become a refractory condition known as 'hyperemesis gravidarum (HG)'. Electrolyte imbalance, ketonuria, weight loss, and occasional need for hospitalization occur in addition to excessive gagging, nausea, and vomiting (6). HG is generally characterized by vomiting for more than 3 days, dehydration, severe dry mouth, decreased skin turgor, and loss of $>5 \%$ of body weight (7).

NVP is very common and affects $70-80 \%$ of patients, whereas the prevalence of $\mathrm{HG}$ is $0.3-0.8 \%$ (8). The role of severe maternal $\mathrm{HG}$ on brain function of both the mother and fetus have not yet been clearly understood. General opinion states that fetal brain develops most prominently in the $3^{\text {rd }}$ trimester and it is most interactive with mother's brain at this stage (9). Significant progression occurs, especially in signal processing, coordination of complex functions, and basic vital functions (10,11). Dehydration, electrolyte imbalance, ketosis, hypokalemia, metabolic alkalosis, increased urea, impairment of liver enzymes and hemoconcentration due to plasma volume loss, and increased hematocrit are typical findings in $\mathrm{HG}(7,12)$. HG is known to show familial susceptibility, and associated with nulliparity, multiple pregnancies, and increased body weight; these factors also interact with growth hormones, gastric electrical activity, lipids, thyroid functions, diet and psychologic conditions $(11,13)$. These events also affect the central nervous system. The neurologic picture varies from loss of muscle strength accompanied by hyporeflexia, ophthalmoparesis, nystagmus, and papillary stasis to comatose state (14).

The aim of this study was to evaluate the effect of disease on the central and autonomic nervous systems by assessing spectral power analyses of electroencephalograph (EEG) signals from women with HG. We suggest a new approach that will help in the differential diagnosis of HG at the clinical level.

\section{Materials and Methods}

Study groups: This study included EEG signals of 30 normal pregnant women who were followed up in the Obstetrics and Gynecology Department of Selçuk University Faculty of Medicine between January 2013 and September 2014, and 33 patients who were diagnosed as having HG.

\section{Results}

Inclusion criteria: Patients aged between 18-40 years, 6-20 weeks of singleton pregnancy, admitted to neurology ward with symptoms of HG (HG criteria were severe nausea-vomiting, limitation of oral intake, weight loss, electrolyte imbalance, and moderate ketonuria), and with no neurologic, hepatic, or gastrointestinal comorbid disorders were selected. Approval from Selçuk University Ethics Committee was obtained and informed consent forms were signed by the patients.

Exclusion criteria were patients aged below 18 or above 40 years of age, twin or triple pregnancies, smoking during pregnancy, had history of an eating disorder/malnutrition, taking medications due to a neurologic, hepatic, or gastrointestinal disorder or refused to sign informed consent form were excluded. No significant difference was found in age distribution of the HG and the control groups (HG group; $27.21 \pm 4.67$ years, control group; $24.87 \pm 6.11$ years). Rate of multiparity and nulliparity slightly increased in the HG group with increasing age. There was no significant difference between pregnancy weeks of the groups (HG group; 11.26 4.17 weeks and control group; 9.89 \pm 5.08 weeks). Additionally, three patients in the HG group and two patients in the control group were left-handed. This difference was not statistically significant. Record of the EEG signals; EEG recordings were performed using a 40-channel Grass-TecCOMET device with the international 1020 evaluation system. Channels for ECG and photic stimulation were removed, which yielded 36 channels for evaluation. Signals in the EEG laboratory were recorded digitally using The European 
Data Format (*.edt), which is a preferable format for storage of multichannel biologic and physical signals, and analyses were made by an experienced engineer using the MATrix LABoratory program. EEG signals are typically divided into 4 frequency domains, namely alpha, beta, delta, and theta $(15,16,17)$. Basic EEG frequency subdomains and their frequencies are given in Table 1. Spectral analysis methods: This study used spectral analysis methods that evaluate periodic and nonperiodic signals in a frequency spectrum. Frequency information hidden in the time axis can be revealed and frequency-power changes can be assessed graphically with this method. The power spectrum of the signals is the square power of frequency amplitudes. The power component shows the ability of that signal to function in the given frequency. The Welch method, which is a nonparametric method of power spectrum analysis, was used in this study. The Welch method calculates periodograms by dividing signal into overlapping windows and then deriving

Table 1. Electroencephalograph sub-band and frequency interval

EEG Frequency interval $(\mathrm{Hz})(\mathrm{c} / \mathrm{sec})$

sub-bands

Delta $\quad 0.5-4$ (Delta $1 ; 0.10-1.48$ and Delta 2; 1.56-3.51)

Theta 4-8 (Theta $1 ; 3.61-5.57$ and Theta 2; 5.66-7.52)

Alpha $\quad$ 8-13 (Alpha 1; 7.62-9.47 and Alpha 2; 9.57-12.50)

Beta 13-30 (Beta 1; 12.60-17.48 and Beta 2; 17.58-30.0)

EEG: Electroencephalograph mean values of these periodograms (18). With regards to the sampling frequency of the EEG device used in this study, frequency resolution was set at $0.1 \mathrm{~Hz}$ intervals. Among the parameters of the Welch method, the overlapping rate was 0.5 , windowing method was Hamming windows, and the window frequency was $128 \mathrm{~Hz}$. Every channel of each patient was analyzed one-by-one using the Welch method and frequency power spectrums were obtained. Figure 1a gives the full extent of EEG signals in Fp1-F7 and F7T3 channels of a healthy subject and Figures $1 \mathrm{~b}$ and $1 \mathrm{c}$ show the power-frequency spectra of the given channels calculated using the Welch method.

All power spectral densities of sub-domains from every channel of each patient were summed at $0.5-4 \mathrm{~Hz}$ delta, $4-8 \mathrm{~Hz}$ theta, $8-13 \mathrm{~Hz}$ alpha, and $13-30 \mathrm{~Hz}$ beta. For every channel, the total power between $0.5-30 \mathrm{~Hz}$ was calculated and then divided to the sum of the powers of all sub domains. In this way, the relative sub-band values were calculated. In order to make patientcontrol comparisons of sub-band data, lists that comprised delta, theta, alpha, and beta were produced. Statistical analyses were performed for same channel and sub frequencies in all patients and the presence of a significant difference according to power density of frequencies was assessed. Hypothesis testing methods for 2 groups were used because there were two independent groups. The Kolmogorov normal distribution test was used to determine whether subfrequency domains complied with subfrequency bands. In the Kolmogorov test, results with a $\mathrm{p}<0.05$ value are not consistent with normal distribution but results with a $\mathrm{p}$ value $>0.05$ are consistent with normal distribution. The t-test was used for bands that were normally distributed and Mann-whitney u test

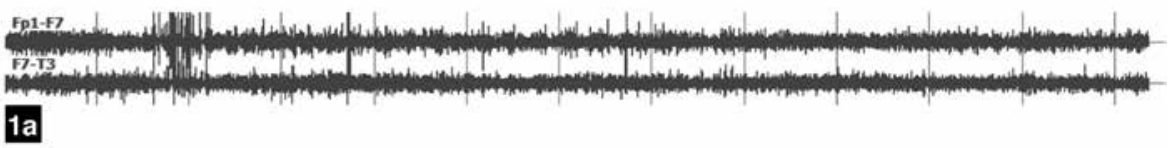

Figure 1a. Condensed electroencephalograph signals for Fp1-F7 and F7-T3 channels

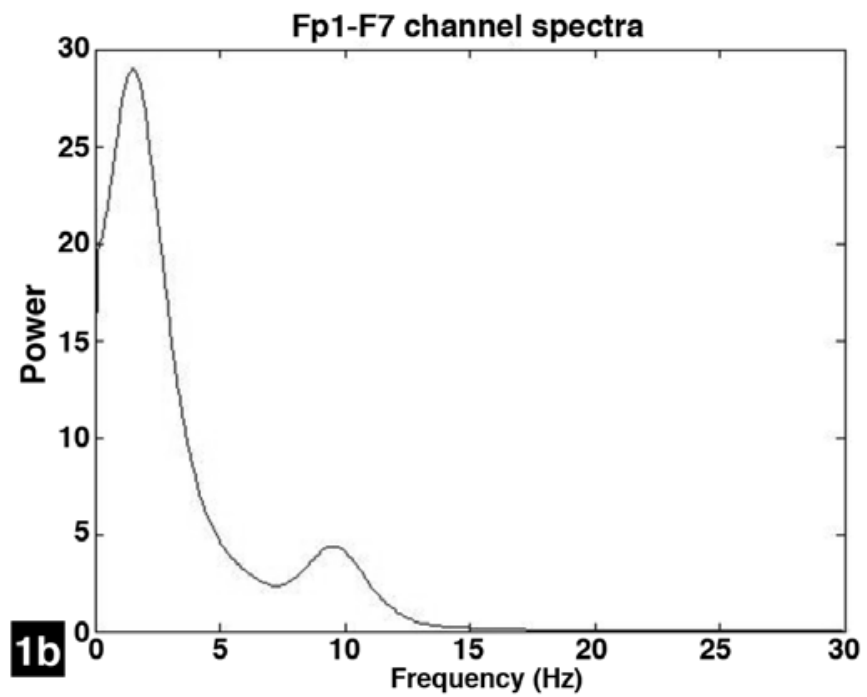

Figure 1b. Frequency-power spectrum for Fp1-F7 channel

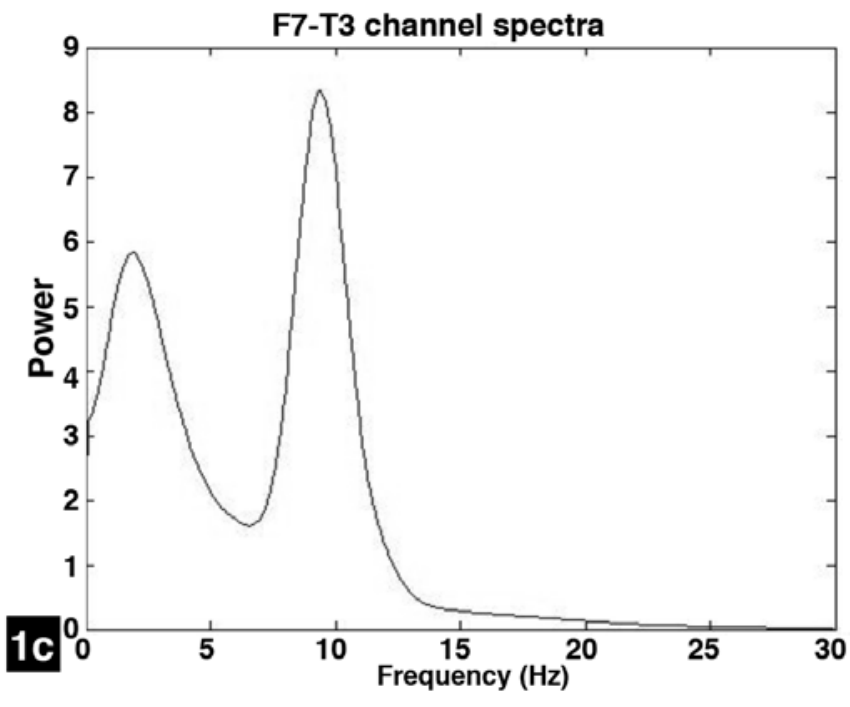

Figure 1c. Frequency-power spectrum for F7-T3 channel (Welch method) 
was used for bands that were not normally distributed. Table 2 shows the results of the Kolmogorov normal distribution test. In this table, channel and band results that did not distribute normally are shown in red. In statistical evaluations, $\mathrm{p}<0.05$ was accepted as statistically significant.

\begin{tabular}{|c|c|c|c|c|}
\hline & Delta & Theta & Alpha & Beta \\
\hline C3P3 & 0.349 & 0.253 & $0.013^{*}$ & 0.004 \\
\hline C4P4 & 0.500 & 0.286 & 0.114 & 0.006 \\
\hline CZPZ & 0.396 & 0.996 & 0.109 & 0.013 \\
\hline F3C3 & 0.768 & 0.824 & 0.189 & 0.085 \\
\hline F4C4 & 0.914 & 0.597 & 0.113 & 0.017 \\
\hline F7T3 & 0.534 & 0.728 & 0.066 & 0.119 \\
\hline F8T4 & 0.960 & 0.930 & 0.370 & $0.002^{*}$ \\
\hline FZCZ & 0.589 & 0.870 & 0.095 & 0.008 \\
\hline Fp1F3 & 0.192 & 0.993 & 0.008 & $0.002^{*}$ \\
\hline Fp1F7 & 0.059 & 0.617 & 0.004 & $0.001^{*}$ \\
\hline $\mathrm{Fp} 2 \mathrm{~F} 4$ & 0.396 & 0.685 & 0.043 & $0.001^{*}$ \\
\hline Fp2F8 & 0.122 & 0.622 & 0.125 & 0.005 \\
\hline P3O1 & 0.652 & 0.596 & 0.171 & 0.009 \\
\hline $\mathrm{P} 4 \mathrm{O} 2$ & 0.176 & 0.302 & 0.253 & 0.005 \\
\hline T3T5 & 0.586 & 0.498 & 0.095 & 0.223 \\
\hline T4T6 & 0.153 & 0.879 & 0.219 & 0.031 \\
\hline T5O1 & 0.326 & 0.811 & 0.489 & 0.037 \\
\hline $\mathrm{T} 6 \mathrm{O} 2$ & 0.272 & 0.253 & 0.390 & 0.012 \\
\hline \multicolumn{5}{|c|}{ Kolmogorov normal distribution test values, ${ }^{*} \mathrm{p}>0.05$} \\
\hline
\end{tabular}

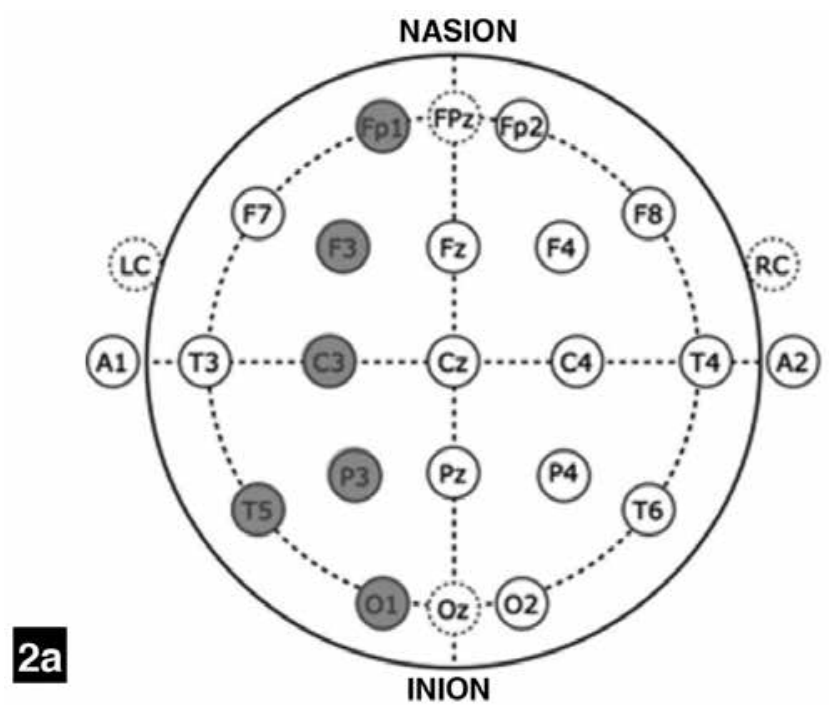

Figure 2a. Channels with significant changes in theta band

\section{Results}

Thirty-three patients with HG were compared with 30 age and sex-matched healthy controls. The nonparametric Welch method was used for power spectrum analysis. Data was obtained for wave frequencies of all cerebral bioelectrical activities. These data included all EEG electrode recording areas of the brain. All waves were classified according to detailed subfrequency groups. Obtained data were statistically compared according to spectral power analysis data (Table 2). Results of appropriate tests and $\mathrm{p}$ values for parameters with normal and non-normal distribution are given in Table 3. Analyses were performed to evaluate whether the mean difference in relative power changes in delta, theta, alpha, or beta sub-bands of the controls and the patients were statistically significant. According to $\mathrm{p}$ values in Table 3, there were significant differences in $\mathrm{Fp} 1 \mathrm{~F} 3$ sub-band in delta and $\mathrm{C} 3 \mathrm{P} 3$, F3C3, Fp1F3, P3O1, T5O1 sub-bands in theta channels but there were no significant changes in other channels or sub-bands $(\mathrm{p}<0.05)$. The mean increase and decrease data for sub-bands that had significant changes are given in Table 4.

According to the results of spectral power analyses, places of cerebral activity (hemispheres and electrode recording areas) that show differences are shown schematically: theta band channels that had significant differences (Figure 2a) and delta band channels that had significant differences are colored in Figure $2 \mathrm{~b}$.

\section{Discussion}

Basis of this study was the content of EEG, which is among the best methods to show central nervous system function during the HG period. However, although EEG evaluation sometimes gives very important findings, it is also very variable. EEG is far from being a diagnostic method in HG, which is not clearly understood and includes multiple factors. Therefore, there are very few studies in the literature and most of them did not use direct methods. Many studies exist in the literature that analyzed EEG in patients with HG. Vaknin et al. (15) used EEG to investigate changes in

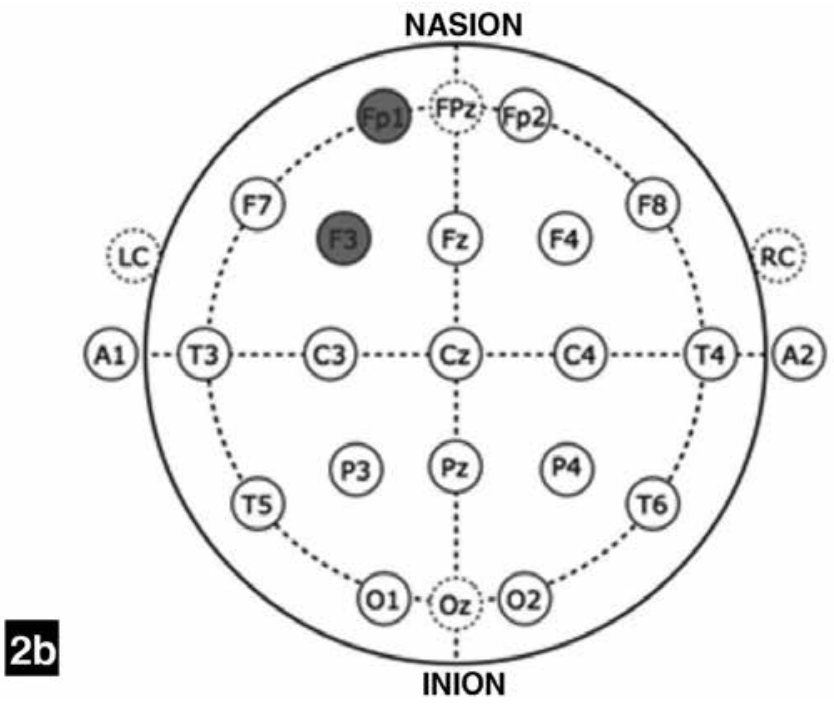

Figure 2b. Channels with significant changes in delta band 
electrical activity of the central nervous system that occurred in patients with HG in the first 3 months of pregnancy. The authors investigated 17 patients with $\mathrm{HG}$ and 18 normal pregnant women; EEG abnormalities were observed in five of 17 patients with HG but none of the controls. Study results showed that patients with HG revealed more pronounced EEG findings than normal pregnant women who had no nausea or vomiting. Many physiologic factors affect EEG evaluations. For example, structured functions like verbal fluency, or weird thought content in women cause more significant cerebral inter-hemispheric asymmetry compared with men (19). Another important difference is the EEG changes during the menstrual period, a decrease in alpha rhythm and increase in theta band power are seen in the follicular phase. During the ovulatory period there is a striking difference in the frontal leads (20). In normal pregnancy, evaluation of EEG spectral analysis changes demonstrated significant changes between trimesters and in the postpartum period. However, hypertension during pregnancy and its effects on EEG activity have been widely investigated (21).

EEG signals are non-periodic signals that have a structural amplitude of $1-100 \mu \mathrm{V}$ and a frequency of $0.5-100 \mathrm{~Hz}(16,22)$. Although they have a wide frequency band, the range between $0.5-30 \mathrm{~Hz}$ has clinical and physiologic significance. Changes in amplitude and frequency are irregular signals that vary according to disease status. It is not logical to ask which signal appears at which time interval because frequency components occur at every

\begin{tabular}{|c|c|c|c|c|}
\hline & Delta & Theta & Alpha & Beta \\
\hline C3P3 & 0.709 & $0.045 *$ & 0.794 & 0.409 \\
\hline C4P4 & 0.638 & 0.509 & 0.442 & 0.630 \\
\hline $\mathrm{CZPZ}$ & 0.925 & 0.105 & 0.522 & 0.417 \\
\hline F3C3 & 0.239 & $0.010^{*}$ & 0.868 & 0.525 \\
\hline $\mathrm{F} 4 \mathrm{C} 4$ & 0.805 & 0.458 & 0.806 & 0.945 \\
\hline F7T3 & 0.915 & 0.149 & 0.534 & 0.561 \\
\hline F8T4 & 0.777 & 0.780 & 0.931 & 0.371 \\
\hline FZCZ & 0.346 & 0.960 & 0.156 & 0.601 \\
\hline Fp1F3 & $0.044^{*}$ & $0.008^{*}$ & 0.104 & 0.093 \\
\hline Fp1F7 & 0.269 & 0.102 & 0.554 & 0.563 \\
\hline $\mathrm{Fp} 2 \mathrm{~F} 4$ & 0.368 & 0.748 & 0.386 & 0.371 \\
\hline Fp2F8 & 0.124 & 0.309 & 0.189 & 0.205 \\
\hline P3O1 & 0.696 & $0.015^{*}$ & 0.259 & 0.826 \\
\hline P4O2 & 0.566 & 0.191 & 0.981 & 0.329 \\
\hline T3T5 & 0.759 & 0.069 & 0.378 & 0.958 \\
\hline T4T6 & 0.857 & 0.249 & 0.804 & 0.582 \\
\hline T5O1 & 0.757 & 0.032 & 0.571 & 0.483 \\
\hline T6O2 & 0.766 & 0.480 & 0.891 & 0.880 \\
\hline \multicolumn{5}{|l|}{${ }^{*} p>0.05$} \\
\hline
\end{tabular}

moment in periodic signals. In non-periodic signals such as EEG, not every frequency component appears in every time period and some frequency components appear and disappear at certain intervals (23). Therefore, it is not possible to observe incident frequency components from time domain signals of routine EEG traces. These data hidden in the time domain may be mapped and frequency components may be observed in the time axis using Fourier transformation. Therefore, we aimed to mathematically analyze EEG data using sub-bands and spectral power analysis, which is explained in detail in the method section. In this way, our target was to determine which brain areas were involved at which rate in these patient groups. Fourier transformation is a mathematical method that divides these signals into cosinus and sinus components, and graphically maps frequency amplitude data; it is a common signal processing technique used for analysis of biomedical signals such as EEG, ECG, and EMG (24). With spectral analysis of routine EEG tracings, level of consciousness and conditions/diseases such as brain trauma (25), epilepsy (26), Alzheimer's disease (27), schizophrenia (28), and sleep disturbances (29) can be analyzed. Spectral analyses are divided as parametric and non-parametric analysis methods. These methods are commonly used signal processing techniques to analyze biomedical signals and for artificial intelligence. The most important finding of our study was the increased mean theta band power, as shown in Table 4 . The mean power was lower in a delta band, which showed significance. The analyses showed that the mean strength of theta bands of $\mathrm{C} 3 \mathrm{P} 3, \mathrm{~F} 3 \mathrm{C} 3$, Fp1F3, P3O1, and T5O1 channels and the delta band of the Fp1F3 channel were significantly different in patients with HG compared with controls. A significant increase in strength was observed, especially in the theta band in the frontocentral, centroparietal, parieto-occipital, and temporo-occipital regions of the left hemisphere. In addition, a decrease in strength of delta band was observed in the whole brain, particularly in the frontal leads of the left hemisphere. The exact pathogenesis of HG is unknown (30).

\begin{tabular}{|c|c|c|c|c|}
\hline $\begin{array}{l}\text { Place of } \\
\text { the lead of } \\
\text { cerebral } \\
\text { record }\end{array}$ & $\begin{array}{l}\text { Band } \\
\text { interval } \\
\text { ( } 1 \text { and } 2 \\
\text { subtypes } \\
\text { together) }\end{array}$ & $\begin{array}{l}\text { Control } \\
\text { group } \\
(n=30)\end{array}$ & $\begin{array}{l}\text { HG } \\
\text { group } \\
(n=33)\end{array}$ & $\begin{array}{l}\text { Power } \\
(\uparrow \downarrow)^{*}\end{array}$ \\
\hline C3P3 & Theta & 0.161598 & 0.202522 & $\uparrow$ \\
\hline F3C3 & Theta & 0.156406 & 0.201330 & $\uparrow$ \\
\hline Fp1F3 & Theta & 0.130940 & 0.171289 & $\uparrow$ \\
\hline Fp1F3 & Delta & 0.765451 & 0.695848 & $\downarrow$ \\
\hline P3O1 & Theta & 0.146482 & 0.190351 & $\uparrow$ \\
\hline T5O1 & Theta & 0.138204 & 0.183205 & $\uparrow$ \\
\hline
\end{tabular}


The most commonly accepted approach is the presence of metabolic and endocrinologic changes stemming from the placenta. NVP occurs when human chorionic gonadotropin level is elevated and human chorionic gonadotropin (hCG) is elevated when NVP is most significant (21). Other proposed factors for $H G$ include the effect of Helicobacter pylori, gastrointestinal dysmotility, and psychogenic factors $(1,5,6,30)$. An important point in gastric and intestinal passage is the dysfunction of enteric nervous system $(10,17)$. HG appears clinically when there is a significant disturbance in sympathetic adrenergic and cholinergic function (10). Vagal innervation is important in homeostasis, satiety, nausea, and sphincter tonus (31). Vagal motor stimulation stimulates both cortical pathways and enteric stretch receptors via nucleus ambiguous $(31,32)$. In this way, it forms the basic mechanism of intestinal movements, gagging, and vomiting. This functions at a microneural level and may play a role in neuromodulation of the primary symptoms of HG (10). The most important complication of HG is electrolyte deficiency and acute thiamine deficiency due to nutritional impairment. This condition is very rare and may lead to Wernicke encephalopathy. Korsakoff syndrome develops after WE (13). At such severe conditions, acute lesions are most prevalent in the periaqueductal and periventricular gray matter, mammillary body, and anterior and medial thalamus. Generalized cortical and subcortical involvement, and multiple cranial nerve involvement may occur and dentate nucleus, caudate nucleus, nucleus ruber, and splenium of corpus callosum may be affected (13). Central pontine myelinolysis is another clinical picture (13). Locations in the brain that are affected in advanced periods of $\mathrm{HG}$ reflect that gastrointestinal autonomic involvement may be important in the pathogenesis of HG and it may affect the cerebral factor. The following mechanism can be proposed to explain left hemispheric localization of cerebral bioelectrical activity in $\mathrm{HG}$ and significant impairment in spectral power distribution of delta and theta bands found in our study.

The first triggering factor in HG development is placental hCG; NTS is stimulated at the brainstem level over vagal and sympathetic adrenergic pathways (1). Discharges from there affect the hypothalamus, amygdala, limbic pathways, other periventricular gray matter areas, subcortical nuclei, and splenium (13). Enteric stimulation that originates from the vagus probably causes neuromodulation in the dominant hemisphere of the brain at our determined regions, especially at slow frequency theta and delta sub-band frequencies.

Using spectral power density, we showed that related localizations of dominant left hemisphere are changed in patients with HG when compared with pregnancies with normal courses. Frontal regions were predominant and central and middle parietal-occipital regions revealed different spectral power; these were the most important findings of our study. The importance of left hemisphere lateralization is the changes in theta and delta band intervals. There was an increase in theta band spectral analysis in tissues next to the left midline. Future research is required using both electrophysiologic methods and complementary methods such as functional MRI to explain both the mechanism of delta spectral power change and their relation with the disease.

\section{Study Limitations}

The most important limitations of this study were the small sample size and low specificity of the methods. However, the role of the brain in HG should be confirmed with functional imaging methods to confirm this important topic.

\section{Ethics}

Ethics Committee Approval: The study was approved by the Selçuk University of Local Ethics Committee.

Informed Consent: Consent forms were filled out by all participants. Peer-review: External and internal peer-reviewed.

\section{Autborship Contributions}

Concept: Hakan Abmet Ekmekçi, Design: Hakan Abmet Ekmekçi, Data Collection or Processing: Hakan Abmet Ekmekçi, Arzu Setenay Yılmaz, Analysis or Interpretation: Hakan Abmet Ekmekçi, Mubammet Üsame Öziç, Yüksel Özbay, Literature Search: Hakan Abmet Ekmekçi, Writing: Hakan Abmet Ekmekçi.

Conflict of Interest: No conflict of interest was declared by the authors. Financial Disclosure: The authors declared that this study has received no financial support.

\section{References}

1. Horn CC. Why is the neurobiology of nausea and vomiting so important? Appetite 2008;50:430-434.

2. Stockhorst U, Steingruebe rHJ, Enck P, Klosterhalfen S. Pavlovian conditioning of nausea and vomiting. Autonomic Neuroscience: Basic and Clinical 2006;129:50-57.

3. Parker LA, Limebeer CL, Kwaitkowska, M. Cannabinoids: effects on vomiting and nausea in animal models. In: Mechoulam, R. editor. Cannabinoids as Therapeutics. Switzerland: Birkhauser Verlag/Switzerland; 2005. p. 183-200.

4. Miraglia L, Pagliarusco S, Bordini E, Martinucci S, Pellegatti M. Metabolic disposition of casopitant, a potent neurokinin-1 receptor antagonist in mice, rats, and dogs. Drug Metab Dispos 2010;38:1876-1891.

5. Sanu O, Lamont RF. Hyperemesis gravidarum: pathogenesis and the use of antiemetic agents. Expert Opn Pharmacother 2011;12:737-748.

6. Goodwin TM. Hyperemesis gravidarum. Obstet Gynecol Clin N Am 2008:35;401-407.

7. Köşger H, İkbal K. Hiperemezis Gravidarum'a güncel yaklaşımlar. Yeni Tip Dergisi 2014;31:159-162.

8. Askling J, Erlandsson G, Kaijser M, Akre O, Ekbom A. Sickness in pregnancy and sex of child. Lancet 1999;354:2053.

9. Keunen RWM, Vliegen JHR, van der Pol DAE, Gerretsen G, Stam CJ. The electroencephalogram during normal third trimester pregnancy and six months postpartum. Bri J of Obstet Gynaecol 1997;104:256-258.

10. Walia R, Aggarwal A, Wadhwa Y. Investigating EEG Characteristics of a Pregnant Women. International Journal of Emergency Medicine 2013;2:14-19.

11. Hughes JD, Nayak NG, Aslam N, Rashed H, Cardoso S, Familoni B, Karas JG, Shaver C, Egerman RS, Wallstedt A, Riely CA, Abell LT. Autonomic and Enteric Nervous System Dysfunction May Play a Role in Hyperemesis Gravidarum. Gastroenterol Res 2015;8:153-156.

12. Goodwin TM. Hyperemesis gravidarum. Clin Obstet Gynecol 1998;41:597605.

13. Abell TL, Riely CA. Hyperemesis gravidarum. Gastroenterol Clin North Am 1992;21:835-849.

14. Zara G, Codemo V, Palmieri A, Schiff S, Cagnin A, Citton V, Manara R. Neurological complications in hyperemesis gravidarum. Neurol Sci 2012;33:133-135.

15. Vaknin Z, Halperin R, Schneider D, Teitler J, Dar P, Herman A, Berkovitch M. Hyperemesis gravidarum and nonspecific abnormal EEG findings: a preliminary report. The Journal of Reproductive Medicine 2006;51:623-627. 
16. Teplan M. Fundamentals of EEG measurement. Measurement Science Review 2002;2:1-11.

17. West M, Parkinson D, Havlicek V. Spectral analysis of electroencephalographic response to experimental concussion in the rat. EEG and Clin Neurophysiol 1982;53:192-200

18. Tokmakci M, Asyali MH, Seğmen, H. Examining EEG signals with parametric and non-parametric analyses methods in migraine patients during pregnancy. In: Biomedical Engineering Meeting. 15th ed. (BIYOMUT), 2010:1-4.

19. Razumnikova OM. Gender differences in hemispheric organization during divergent thinking; an EEG investigation in human subjects. Neurosci Lett 2004;362:193-195.

20. Vasil'eva VV. Spectral and coherent characteristics of EEG in women during various phases of menstrual cycle. Bull ExpBiol Med 2005;140:383-384.

21. Brussé IA, Peters NCJ, Steegers EAP, Duvekot JJ; Visser GH. Electroencephalography during Normotensive and Hypertensive Pregnancy: A systemic Review. Obs and Gyn Survey 2011;65:794-803.

22. Rao SVM, Koya JR, MandadiNK, Mitta SK. Electroencephalographic signals for recognizing speaking effort-brain computer interface 2013;8:6267.

23. Adeli H, Zhou Z, Dadmehr N. Analysis of EEG records in an epileptic patient using wavelet transform. Journal of Neuroscience Methods 2003;123:69-87.

24. John LS. Biosignal and Biomedical Image Processing. In Marcel Dekker, MATLAB based Applications. NY, 2004:271-301.
25. Goldfine AM, Victor JD, Conte MM, Bardin JC, Schiff ND. Determination of awareness in patients with severe brain injury using EEG power spectral analysis. Clinical Neurophysiology 2011;122:2157-2168.

26. Direito B, Teixeira C, Ribeiro B, Castelo-Branco M, Sales F, Dourado A Modeling epileptic brain states using EEG spectral analysis and topographic mapping. Journal of Neuroscience Methods 2012;210:220-229.

27. McBride JC, Zhao X, Munro NB, Smith CD, Jicha GA, Hively L, Jiang Y. Spectral and complexity analysis of scalp EEG characteristics for mild cognitive impairment and early Alzheimer's disease. Computer Methods and Programs in Biomedicine 2014;114:153-163.

28. John JP, Rangaswamy M, Thennarasu K, Khanna S, Nagaraj RB, Mukundan CR, Pradhan N. EEG power spectra differentiate positive and negative subgroups in neuroleptic-naive schizophrenia patients. J Neuropsychiatry Clin Neurosci 2009;21:160-172.

29. Lundahl J, Deacon S, Maurice D, Staner L. EEG spectral power density profiles during NREM sleep for gaboxadol and zolpidem in patients with primary insomnia. Journal of Psychopharmacology 2012;26:1081-1087.

30. Lee NM, Saha S. Nausea and Vomiting of Pregnancy. Gastroenterol Clin North Am 2011;40:309-334.

31. Ratcliffe EM, Farrar NR, Fox EA. Development of the vagal innervation of the gut: steering the wandering nerve. Neurogastroenterol Motil 2011;23:898911

32. Phillips RJ, Powley TL. Tension and stretch receptors in gastrointestinal smooth muscle: reevaluating vagal mechanoreceptor electrophysiology. Brain Research 2000;34:1-26. 